\title{
AN EXPERIMENT ON GETTING AN AFTER-IMAGE FROM A MENTAL IMAGE.
}

\author{
BY JUNE E. DOWNEY.
}

\section{University of Wyoming.}

In the literature of the subject one finds a deplorable lack of detail both as regards methods used and results obtained. Leaving out of consideration the experiments conducted on hypnotized persons, the classic references are to the cases of Féré and Meyers and to the general statements of Wundt. The great difficulty that suggests itself to even the most casual reader of the passages in question is the one upon which Dr. Franz lays stress in his monograph upon after-images, namely, that the subject, who, in the nature of the case, must be an exceptionally vivid visualizer, could very well suggest a sequence of colors corresponding to after-image effects unless this possibility were ruled out by the subject's absolute ignorance of the very existence of after-images.

That the subject should be naive as regards after-images is the first and paramount requirement for the success of the experiment. Other requirements and precautions suggest themselves, however. The subject must have his mental images under control; he must be able to hold them for a certain length of time; he must, moreover, be to a certain degree a trained observer-that is, able to observe and to report accurately upon color sequences. Usually, in work upon after-images, constancy in result is held to be the test of the trained observer, and yet even under the most unvarying objective conditions variations in the results obtained from any one individual will occur. Naturally one would expect to find this difficulty increased in dealing with mental images where the attributes of quality, intensity and duration could not be kept absolutely constant. Variation in result is usually balanced by frequent repetition of the experiment. But in the problems under consideration even 
repetition has its dangers. How during these repetitions is the subject to be kept from suggesting a sequence of color once obtained? Conditions, of course, might be varied, or a sufficiently long time-interval might occur between the experiments to rule out self-suggestion due to conscious memory, but the effect of subconscious memory would remain. How serious the operations of subconscious memory might be the writer is not able to judge.

Since the colored after-images, even in those whose colorvision is classed as normal, vary widely within certain limits the results of any experiment upon the topic could be tested only by a comparison with the after-images obtained by the subject from a series of actually presented colors. Even so, discrepancies could not always be interpreted unfavorably, for variations, as said, may occur in any individual case. Within limits, in deed, variation would be favorable evidence, inasmuch as it would show the absence of self-suggestion.

The writer has been able to carry out a series of experiments on the after-images of mental images under the above-mentioned conditions. The greatest difficulty experienced was the finding a satisfactory subject. A great many students were tested, and although several were found who could visualize colors readily and vividly, yet work with them usually disclosed the fact that their images were not under control, could not be held for any length of time, could not be projected upon outer surfaces, etc. While several trials with different subjects were more or less successful, the experiments could not be carried far enough to justify any conclusions. An entirely satisfactory subject was finally found.

The subject was a girl in her twenty-first year, a junior in college in the classical course, her work being almost entirely confined to the languages. As regards after-images she was absolutely naive. For the rest she is a good student, and not only an exceptionally good visualizer, but also accurate as to the memory and discrimination of colors.

The experiments were tried carefully. During the experiments, as far as possible, the eyes were kept from all stimulation other than light reflected from a white or black surface. In the majority of the experiments the colors were visualized 
upon a white background, and, after they had been held for some seconds, the eyes were closed. Sometimes the background upon which the colors were visualized was changed; sometimes the after-image was projected upon some background other than the retinal light. The subject was asked to observe and to report carefully all experiences. Unfortunately not all the conditions could be kept absolutely constant. It was not possible to try all the experiments at the same hour of the day, nor at the most satisfactory hour. Usually the time given to the experiments was at the close of the day's recitations, when the subject was fatigued to a greater or less degree. During the early part of the morning the subject could visualize more readily and more vividly than later in the day. The experiments seemed to tire the eyes as would working with actual colors.

The aim of the experiment was to test other-colored afterimages, and therefore the time of holding the mental images was made long. Nevertheless, positive after-images were noticed on several occasions as the records show. No attempt was made to keep the time of holding the mental image constant. The subject was not always able to hold the color a required time, and was instructed to close her eyes if she felt the image leaving her. The subject was also allowed to choose the form which the color should take. The order in which the colors were visualized in the different series was carefully varied; in particular, complementary colors rarely followed one another. The results, in general, show no error arising from this cause, and so this record, although carefully kept, is not included in the account. Every effort was made to rule out expectation by means of constant variations in the manner of conducting the experiment. When possible the subject matched the color of the mental image and the after-image on the Bradley color-top. No suggestion was ever made as to the object of the experiment and the casual remarks of the subject were interesting. "I can't see what you can get from these experiments, for the results are never the same twice," etc. At the beginning of each series the subject was questioned, as indirectly as possible, as to her memory of the previous results. She usually answered: "I haven't tried to remember." "I can't remember." She had 
been instructed not to use effort to recall any of the results. October 23, she was, for the first time, asked to use effort and to remember what she could. "Of course I can't recall all, because the results were very different. I know that several times I got a black image after visualizing red. Once I got red after visualizing green. I can't remember what came after orange. Sometimes I got blue after yellow and I believe once I got orange after violet."

The girl is not particularly suggestible, nor, on the other hand, open to contrary suggestion. A trial was made both with visualized and presented colors in which a color sequence was suggested. In the case of the visualized colors out of eight experiments the true after-image came first five times, and had to be suppressed with effort before the color suggested could be visualized. In two experiments there came a perceptible blank interval and then the suggested color. In one instance the suggestion operated to remove all images. These experiments are included in the tables summarizing tne sesults obtained from the different colors. In the case of the presented colors, now used for the first time, suggestion had in five experiments no effect whatever. In two other instances it operated to banish after-images altogether. In the further tests with actual colors the subject was asked if she thought she could control the color of the after-image. She thought not. The writer has never been able to change the color of an after-image in the slightest degree. That expectation could emphasize one color of a compound, the yellow or red of orange, for instance, is, however, conceivable.

In order to test the relative vividness of the color-tones of the mental images as compared with actually presented colors, an experiment was tried in which the visualized images were thrown upon colored backgrounds and after-images obtained from the combinations. The writer's faith in the color-intensity of the images was so slight that she fully expected failure in the attempt. The results did not confirm her expectations. On the contrary, the subject found no difficulty in throwing her mental images upon the most brilliant background. When questioned as to the relative intensity of the colors she maintained that they were about equal. The visualized disc completely hid the color 
lying underneath. In three cases, namely, orange visualized on blue, blue on orange, and green on red, the colors fused, giving gray. Out of eleven trials, in only two cases was the subject unable to throw her mental image upon the required background. The after-inages obtained from the combination of visualized and presented colors are included in the tables.

Two or three unsuccessful attempts were made to throw the after-images from a mental image upon a colored background. Unfortunately, circumstances made it necessary to bring the experiments to a close and further work along this line had to be given up.

At the close of the experiment the subject was required to get and to match carefully on the color-tops a set of after-images from the six spectral colors. The other conditions were kept constant. No explanations were made, but the subject was encouraged to compare as far as memory permitted both the visualized colors with the actual colors and the results in the two sets of after-images. The comparisons, which were highly instructive, are given below.

It will be noticed in going over the tables that the results obtained from green are practically constant, varying between brownish-red through spectral red to pinkish-violet. This table is the most satisfactory of the six. The results obtained from red are also conclusive, although by no means satisfactory. In the series of black after-images found in this table suggestion was doubtless operative, as remarked by the subject herself. The results from orange and violet were also practically constant, a blue-violet for the one, a yellow-orange for the other. Blue was the hardest color for the subject to visualize and the hardest to hold any length of time. Though a large number of experiments in this series were without result, those giving colors were, for the most part, favorable, showing yellow as the after-image. The results from yellow are unsatisfactory. While a violet or blue occurs in most of the experiments, it often came supplementary, as it were, to some other color.

In summarizing the results by numbering the colors obtained from any given image it is to be remembered that the true afterimage, so to speak, was sometimes accompanied by little blotches 
of other colors, and these are included in the summaries. A reference to the table will show just the relation between the colors where two or more came together.

In several instances the forms of the mental and after-images were different. In general as regards the disc seen as afterimages both of the mental image and the actually presented disc the subject observed that it appeared to lie on an inclined surface; that is, it appeared oval rather than perfectly round.

In considering the results of the experiments the writer was, at first, puzzled by what had been obtained in the case of blue, orange and violet. Her own experience with after-images gives with closed eyes, blood-orange for blue, brilliant blue for orange, bright yellow for violet. The subject visualized a blue that was lighter than spectral, and a yellow-orange rather than a spectral orange. The results obtained from actually presented colors confirmed those obtained from the visualized series. As a matter of interest each member of the writer's psychology class of the present year was required to match carefully on the colortop his other-colored after-images from the six spectral colors. The individual differences were highly instructive. As typical are given the results obtained by four members of the class for spectral blue, the objective conditions being practically the same for all: $A$, cream (I9 white plus I spectral yellow); $B$, light orange (I9 spectral orange plus I white); $C$, yellow (I4 white plus 6 spectral yellow); $D$, greenish-yellow ( 2 spectral orange plus 8 spectral green).

In conclusion, it may be said that although no exact quantitative measurements were attempted the writer believes that the experiment, as conducted, offers good evidence for the getting of an after-image from a mental image. It is, however, admitted that possibility of error was not wholly overcome; most serious being the effect of subconscious memory and, consequently, self-suggestion. The subject, who commenced the study of psychology this September, had, at its close, the object of the experiment carefully explained to her and her opinion was asked as to the results. Personally she is convinced of getting after-images from her mental images but, of course, her testimony has no absolute value. The reader may draw his own conclusions from the tables given below. 
TABLE I.

\begin{tabular}{|c|c|c|c|c|c|c|c|c|}
\hline & & MENTAL & IMAGE. & & & AFTER-IS & SAGE. & \\
\hline Date. & No. & Color & Form & $\begin{array}{l}\text { Back- } \\
\text { ground } \\
\text { upon } \\
\text { which } \\
\text { thrown }\end{array}$ & $\begin{array}{l}\text { Time } \\
\text { of } \\
\text { hold- } \\
\text { ing }\end{array}$ & Color. & Form. & $\begin{array}{c}\text { Back- } \\
\text { ground } \\
\text { upon } \\
\text { which } \\
\text { thrown. }\end{array}$ \\
\hline $\begin{array}{l}\text { Dec. I, '99 } \\
\text { Feb. } 7\end{array}$ & 1 & Orange & Cross & White & $20 s$ & White. & Cross & White \\
\hline & 2 & & & & $45^{\mathrm{s}}$ & $\begin{array}{l}\text { Green, orange and } \\
\text { lavender in sec- } \\
\text { tions. }\end{array}$ & $\begin{array}{c}\text { No } \\
\text { record }\end{array}$ & $\begin{array}{c}\text { Retinat } \\
\text { light }\end{array}$ \\
\hline 4 & 3 & “ & “ & “" & 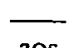 & Violet. & Cross & $\because$ \\
\hline $\begin{array}{l}\text { Mar. 7,'> } \\
\text { Mar. 14, 'to }\end{array}$ & 4 & “" & "، & $\begin{array}{c}\text { White } \\
\text { ، }\end{array}$ & $\begin{array}{l}305 \\
405\end{array}$ & $\begin{array}{l}\text { Violet (spectral). } \\
\text { Violet or purple } \\
\text { with green edge. }\end{array}$ & $\because "$ & " \\
\hline ، & 6 & “" & “ & "، & $4^{\circ}$ & $\begin{array}{l}\text { Deep violet, little } \\
\text { green around edge. }\end{array}$ & ، & " \\
\hline “ & 7 & '6 & “" & "“ & fos & $\begin{array}{l}\text { Orange with spec- } \\
\text { tral violet around. }\end{array}$ & " & ، \\
\hline Mar. 22, 'co & 8 & " & Circle & "، & $45 \mathrm{~s}$ & $\begin{array}{l}\text { Heliotrope. } \\
\text { Matched on color- } \\
\text { top (shade of vio- }\end{array}$ & )( & “، \\
\hline “ & 9 & “ &. & " & $35 \mathrm{~s}$ & $\begin{array}{l}\text { Green (1o sec.) then } \\
\text { violet shade. }\end{array}$ & Circle & " \\
\hline Sept. 28 , ' & Io & “6 & Disc & Black & ${ }_{15} \mathrm{~s}$ & Violet. & $\begin{array}{l}\text { Dis't } \\
\text { Disc }\end{array}$ & “" \\
\hline Oct. 23, 'oo & II & " & " & White & 3 os & $\begin{array}{l}\text { Blue-violet (then } \\
\text { green around the } \\
\text { violet. Green had } \\
\text { been suggested). }\end{array}$ & Disc & “ \\
\hline Oct. $24, ' \infty$ & 12 & "، & “ & ““ & $20 \mathrm{~s}$ & $\begin{array}{l}\text { Violet-blue (blue } \\
\text { had been sug- } \\
\text { gested). }\end{array}$ & “" & “. \\
\hline “ & I3 & ، & “، & $\begin{array}{l}\text { Blue } \\
\text { Square }\end{array}$ & 208 & No result. & & “" \\
\hline " & 14 & ، & i & $\begin{array}{l}\text { Blue } \\
\text { square } \\
\vdots\end{array}$ & $20 s$ & $\begin{array}{l}\text { Big y ellow square } \\
\text { with little violet } \\
\text { disc inside. } \\
\text { Around yellow } \\
\text { square a margin } \\
\text { of blue. }\end{array}$ & Disc & “" \\
\hline
\end{tabular}

Summary of Results for Orange. (Table I.)

Total number of experiments, 14 .

Number of experiments without result, I.

After-color: Violet hues, 12 ; orange, 2 ; white, I ; green, 5 . (Note.-In No. 5 and No. 6 the green appeared as a border edging the violet; in No. 2 as a section accompanying orange and lavender; in No. 9 green appeared first, giving way after Io seconds to violet; in No. I I green had been suggested as after-effect and it appeared around the violet after the subject had made an effort to visualize it.) 


\section{Experiment with Presented Orange.}

On the closing of the eyes, after they had been stimulated for 30 seconds by spectral orange upon a white background, the after-image was described as bluish-green and matched by 8 spectral blue plus 12 spectral green. The subject observed that the orange she visualized was not as red as the spectral orange. She matched from memory the orange she had been visualizing as $9 \frac{\pi}{2}$ spectral yellow plus Io $1 / 2$ spectral orange. The after-image from this was matched by 2 light green plus I8 spectral violet.

TABLE II.

\begin{tabular}{|c|c|c|c|c|c|c|c|c|}
\hline \multirow[b]{2}{*}{ Date. } & \multicolumn{5}{|c|}{ MENTAL IMAGE } & \multicolumn{3}{|c|}{ AFTER-IMAGE } \\
\hline & No. & Color. & Form. & $\begin{array}{l}\text { Back- } \\
\text { ground } \\
\text { upou } \\
\text { which } \\
\text { thrown }\end{array}$ & $\begin{array}{l}\text { Time } \\
\text { of } \\
\text { hold- } \\
\text { 1ng. }\end{array}$ & Color. & Form. & $\begin{array}{l}\text { Back } \\
\text { ground } \\
\text { upon } \\
\text { which } \\
\text { thrown }\end{array}$ \\
\hline Dec. 1, '99 & $\begin{array}{l}1 \\
2\end{array}$ & Blue. & Cross. & $\begin{array}{l}\text { White. } \\
\text { Seen } \\
\text { in air. }\end{array}$ & $\begin{array}{l}205 \\
205\end{array}$ & $\begin{array}{l}\text { Yellow. } \\
\text { Red with violet } \\
\text { tinge. }\end{array}$ & Cross & $\begin{array}{l}\text { White } \\
\text { Reti- } \\
\text { nal } \\
\text { light }\end{array}$ \\
\hline Feb. 7$]^{\prime} \infty$ & $\begin{array}{l}3 \\
4\end{array}$ & “" & “6 & $\underset{\text { Black ? }}{ }$ & $\begin{array}{l}30 \mathrm{~s} \\
30 \mathrm{~s}\end{array}$ & No results. & & 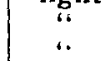 \\
\hline Mar. $7,{ }^{\prime} \infty$ & 5 & Spectral & “" & White & 305 & $\begin{array}{l}\text { Dark green } \\
\text { changed to spectral } \\
\text { yellow. }\end{array}$ & Cross & “ \\
\hline “ & 6 & “ & “ & “" & $35 \mathrm{~s}$ & $\begin{array}{l}\text { Green with yellow } \\
\text { outside. }\end{array}$ & “ & “" \\
\hline Mar. 14, 'oo & 7 & $\begin{array}{l}\text { Blue } \\
\text { tint. }\end{array}$ & Disc. & ": & $35^{5}$ & $\begin{array}{l}\text { Yellow with pink } \\
\text { border }\end{array}$ & Disc & “" \\
\hline “ & 8 & $" “$ & “" & “" & $35 s$ & $\begin{array}{l}\text { No results. } \\
\text { “. }\end{array}$ & & “ \\
\hline “ & $\begin{array}{r}9 \\
\text { เo }\end{array}$ & “ & “ & “ & $\begin{array}{l}35^{5} \\
5 \text { Os }\end{array}$ & Spectral yellow not & Disc & “" \\
\hline Mar. 22, 'oo & II & Spectral & Cross. & “ & $35^{6}$ & $\begin{array}{l}\text { bright. } \\
\text { No results. }\end{array}$ & & \\
\hline "1 & 12 & a & Circle & “ & 505 & Spectral yellow. & Disc & “ \\
\hline Sept. 28, , 'oo & $\begin{array}{l}13 \\
14\end{array}$ & "6 & Disc. & $\underset{\text { Black. }}{\text { B }}$ & $\begin{array}{l}225 \\
205\end{array}$ & $\begin{array}{l}\text { No results. } \\
\text { Yellow streak. }\end{array}$ & Streak & “" \\
\hline Oct. $23, ' \infty$ & 15 & “" & “ & White. & I5s & $\begin{array}{l}\text { Bright yellow } \\
\text { streaks. }\end{array}$ & Streaks & "“ \\
\hline “ & 16 & “ & " & $\begin{array}{l}\text { Red } \\
\text { square. }\end{array}$ & $\begin{array}{l}\text { No } \\
\text { Rec. }\end{array}$ & $\begin{array}{l}\text { Big green square } \\
\text { xith snall red } \\
\text { disc inside, then } \\
\text { blue disc. }\end{array}$ & Disc & . \\
\hline Oct. $24, ' \infty$ & 17 & " & " & White. & 205 & $\begin{array}{l}\text { Yellow then red. } \\
\text { Red had been sug- } \\
\text { gested. }\end{array}$ & " & “ \\
\hline “ & 18 & “ & “ & $\begin{array}{l}\text { Orange } \\
\text { square. }\end{array}$ & $23^{8}$ & $\begin{array}{l}\text { Greenish-blue } \\
\text { square which } \\
\text { changed to violet } \\
\text { square, then yel- } \\
\text { low appeared } \\
\text { around edges of } \\
\text { the violet. }\end{array}$ & & " \\
\hline
\end{tabular}


Summary of Results for Blue. (Table II.)

Total number of experiments, I8.

Number of experiments without result, 7 .

After-colors: Yellow, 9; red, 3; green, 2; pink, I.

(Note.-In No. I7 red had been suggested as after-image. It came with effort after the yellow had been suppressed. In No. 7 the pink was matched by to orange plus Io white.)

\section{Experiment with Presented Blue.}

On the closing of the eyes, after they had been stimulated for 30 seconds by spectral blue upon a white background, the

TABLE III.

\begin{tabular}{|c|c|c|c|c|c|c|c|c|}
\hline \multirow{2}{*}{ Date } & \multicolumn{5}{|c|}{ Mental image. } & \multicolumn{3}{|c|}{ AFTER-IMAGE } \\
\hline & No & Color & Form & $\begin{array}{c}\text { Back- } \\
\text { ground } \\
\text { upon } \\
\text { which } \\
\text { thrown. }\end{array}$ & $\begin{array}{l}\text { Time } \\
\text { of } \\
\text { hold- } \\
\text { ing. }\end{array}$ & Color & Form. & $\begin{array}{l}\text { Back- } \\
\text { ground } \\
\text { upon } \\
\text { which } \\
\text { thrown }\end{array}$ \\
\hline Dec. I, '99 & $\begin{array}{l}I \\
2\end{array}$ & Yellow & Cross & White & $\begin{array}{l}205 \\
205\end{array}$ & $\begin{array}{l}\text { Red. } \\
\text { No results (eyes } \\
\text { tired). }\end{array}$ & Cross & $\begin{array}{l}\text { White } \\
\text { Retinal } \\
\text { light }\end{array}$ \\
\hline Feb. $7, ?, \infty$ & 3 & “" & “ & Black & $\begin{array}{l}40 s \\
405\end{array}$ & Deep green. & “" & i6 \\
\hline Mar. $7,{ }^{\prime} \infty$ & 5 & “ & ‘. & White & 305 & $\begin{array}{l}\text { Green, gentian pink } \\
\text { or violet around } \\
\text { edges. }\end{array}$ & " & " \\
\hline Mar. I4, & $\begin{array}{l}6 \\
7\end{array}$ & “ & ". & “" & $\begin{array}{l}355 \\
405\end{array}$ & $\begin{array}{l}\text { Green. } \\
\text { Green then violet at } \\
\text { top. }\end{array}$ & "“ & $\because$ \\
\hline Mar. 22, 'oo & $S$ & " & Circle & " & $4^{\circ}$ & $\begin{array}{l}\text { Green, not vivid, } \\
\text { (10 green and 10 }\end{array}$ & Circle & . \\
\hline ept. $28, \infty$ & 9 & “, & " Diser & P1" & $3.5 \mathrm{~s}$ & Blue tint, small. & in: & $\because$ \\
\hline Sept. $28, \infty$ & $\begin{array}{l}10 \\
11\end{array}$ & “" & "Disc & $\underset{" \text { Black }}{ }$ & $\begin{array}{l}205 \\
155\end{array}$ & $\begin{array}{l}\text { "Y Yellow. } \\
\text { Green and violet. }\end{array}$ & Disc & .. \\
\hline Oct. 23, 'o & I2 & “ & " & White & $25 s$ & $\begin{array}{l}\text { Blue disc with yel- } \\
\text { low. }\end{array}$ & ; & ، \\
\hline “ & I3 & " & “ & “ & 205 & $\begin{array}{l}\text { Blank interval then } \\
\text { violet. Violet had } \\
\text { been suggested. }\end{array}$ & “ & " \\
\hline Oct. $24, \infty$ & 14 & “” & “ & $\begin{array}{l}\text { Violet } \\
\text { square }\end{array}$ & $25 \mathrm{~s}$ & $\begin{array}{l}\text { Big yellow square; } \\
\text { inside of it orange } \\
\text { and blue discs. }\end{array}$ & " & “" \\
\hline “" & 15 & “" & “. & $\begin{array}{l}\text { Green } \\
\text { square }\end{array}$ & $17 \mathrm{~s}$ & $\begin{array}{l}\text { Big pinkish-red } \\
\text { square, no disc. } \\
\text { Light blue of no } \\
\text { definite shape ar'd } \\
\text { the disc. This } \\
\text { blue was probably } \\
\text { due to contrast } \\
\text { and is omitted in } \\
\text { the summary. }\end{array}$ & " & " \\
\hline
\end{tabular}


after-image was described as yellow and matched by 5 orange plus 15 yellow. The blue visualized was judged to be somewhat lighter than spectral blue.

TABle IV.

\begin{tabular}{|c|c|c|c|c|c|c|c|c|}
\hline \multicolumn{6}{|c|}{ MENTal Image. } & \multicolumn{3}{|c|}{ AFTEK-IMAGE } \\
\hline Date. & No & Color. & Form & $\begin{array}{l}\text { Back- } \\
\text { ground } \\
\text { upon } \\
\text { which } \\
\text { thrown }\end{array}$ & $\begin{array}{c}\text { Tinue } \\
\text { of } \\
\text { hold- } \\
\text { ing }\end{array}$ & Color. & Form. & $\begin{array}{l}\text { Back- } \\
\text { ground } \\
\text { upon } \\
\text { which } \\
\text { thrown. }\end{array}$ \\
\hline Dec. I. '99 & I & Violet. & Cross. & White. & 20 & $\begin{array}{l}\text { Orange or deep yel- } \\
\text { low (yellow } 9 \text { and } \\
\text { orange } 11) \text {. }\end{array}$ & Cross. & White. \\
\hline “ & 2 & "“ & $\begin{array}{l}\text { Tri- } \\
\text { angle. }\end{array}$ & 1 & 205 & $\begin{array}{l}\text { Violet with orange } \\
\text { around. }\end{array}$ & $\begin{array}{l}\text { Tri- } \\
\text { angle. }\end{array}$ & “ \\
\hline ". & 3 & “" & Cross. & In air. & 209 & $\begin{array}{l}9 \text { yellow }+11 \\
\text { orange. }\end{array}$ & Cross. & “" \\
\hline eb. $7, \infty$ & 4 & $\begin{array}{l}\text { Light } \\
\text { Violet. }\end{array}$ & i & Blach. & $30 s$ & 2 yellow +18 & ، & $\begin{array}{l}\text { Retinal } \\
\text { light. }\end{array}$ \\
\hline 3 & 5 & V: & “" & whit & $30 s$ & $\begin{array}{l}2 \text { yellow }+ \text { is } \\
\text { orangre. }\end{array}$ & " & \\
\hline Mar. $7, \infty$ & 6 & $\begin{array}{l}\text { Violet } \\
\text { (Spec- } \\
\text { tral). }\end{array}$ & "“ & White. & $3^{\circ}$ & $\begin{array}{l}\text { Orange in center, } \\
\text { green outside. } \\
\text { When eyes opened } \\
\text { quickly saw iolet; } \\
\text { when closed, } \\
\text { orange-yellow. }\end{array}$ & “. & " \\
\hline Miar. 14, 'o & 7 & Violet. & “" & " & $30 \mathrm{~s}$ & $\begin{array}{l}\text { Orange, green for an } \\
\text { instant at one cor- } \\
\text { ner. }\end{array}$ & " & “. \\
\hline Mar. 22, 'oo & $S$ & $\begin{array}{l}\text { Light } \\
\text { Violet. }\end{array}$ & Circle & “" & $45 \mathrm{~s}$ & Orange. & Circle & “ \\
\hline Sept. $2 S$, 'o & 9 & ." & Disc. & Black. & $12 \mathrm{~s}$ & $\begin{array}{l}\text { Two squares; one } \\
\text { orange ( } 7 / 2 \text { yellow } \\
+121 / 2 \text { orange), } \\
\text { the other violet } \\
\text { with green at bot- } \\
\text { tom. The green } \\
\text { and violet square } \\
\text { vanished first. }\end{array}$ & & “ \\
\hline Oct. 23, , & Io & Violet. & "“ & $\begin{array}{l}\text { Yellow } \\
\text { square. }\end{array}$ & 155 & $\begin{array}{l}\text { Large violet square, } \\
\text { small yellow disc. }\end{array}$ & Disc. & "s \\
\hline Oct. 24, 'oo & $1 \mathrm{i}$ & " & $\because$ & White. & $\begin{array}{l}\text { No } \\
\text { record }\end{array}$ & $\begin{array}{l}\text { Nothing, then blue. } \\
\text { Blue had been sug- } \\
\text { grested as an after- } \\
\text { image. }\end{array}$ & "“ & “" \\
\hline “" & $\begin{array}{l}12 \\
13\end{array}$ & "، & $\because$ & $\begin{array}{l}\text { Yellow } \\
\text { square. }\end{array}$ & $\begin{array}{l}204 \\
154\end{array}$ & $\begin{array}{l}\text { No result. } \\
\text { Large violet square, } \\
\text { a small yellow disc } \\
\text { within. }\end{array}$ & “" & “. \\
\hline
\end{tabular}

Summary of Results for Yellow. (Table III.)

Total number of experiments, 15 .

Number of experiments without result, 2. 
After-colors: Violet or blue, 7 ; yellow, 2 ; red, 1 ; green, 7 . (Note.-In No. 5 and No. 7 the violet edged the green. In

TABLE V.

\begin{tabular}{|c|c|c|c|c|c|c|c|c|}
\hline \multicolumn{6}{|c|}{ MENTAL IMAge. } & \multicolumn{3}{|c|}{ AFTER-IMAGE. } \\
\hline Date. & No. & Color & Porm & $\begin{array}{l}\text { Rack- } \\
\text { ground } \\
\text { upon } \\
\text { which } \\
\text { thrown }\end{array}$ & $\begin{array}{l}\text { Time } \\
\text { of } \\
\text { hold. } \\
\text { ing. }\end{array}$ & Color & Form. & $\begin{array}{c}\text { Back- } \\
\text { ground } \\
\text { woon } \\
\text { which } \\
\text { thrown }\end{array}$ \\
\hline Dec. 1, '99 & $\begin{array}{l}I \\
2\end{array}$ & $\begin{array}{l}\text { Red. } \\
\text { Dark } \\
\text { red. }\end{array}$ & Cross. & $\begin{array}{l}\text { White. } \\
\text { In air. }\end{array}$ & $\begin{array}{l}205 \\
20 s\end{array}$ & $\begin{array}{l}\text { Black. } \\
\text { Dark green with red } \\
\text { around. }\end{array}$ & Cross. & $\begin{array}{l}\text { White. } \\
\text { Retinal } \\
\text { light. }\end{array}$ \\
\hline Feb. 7,99 & 3 & Scarlet. & " & Black. & $\begin{array}{l}\text { No } \\
\text { Rec. }\end{array}$ & Spectral yellow. & “" & \\
\hline ." & 4 & $\begin{array}{l}\text { Bright } \\
\text { red. }\end{array}$ & " & "“ & ". & Spectral yellow. & . & " \\
\hline Mar. 7, '99 & 5 & $\begin{array}{l}\text { Crim- } \\
\text { son. }\end{array}$ & “" & White. & $30 \mathrm{~s}$ & $\begin{array}{l}\text { Black with dark } \\
\text { green around. }\end{array}$ & Sq. & " \\
\hline Mar. 14, '99 & 6 & Red. & $\begin{array}{l}\text { No } \\
\text { Rec. }\end{array}$ & "، & $\begin{array}{l}\text { No } \\
\text { Rec. }\end{array}$ & $\begin{array}{l}\text { Square, black-blue, } \\
\text { changed to black- } \\
\text { yellow. }\end{array}$ & " & " \\
\hline " & 7 & " & " & “ & 405 & $\begin{array}{l}\text { Black (probably due } \\
\text { to self-suggestion, } \\
\text { "I'll see black bor- } \\
\text { dered with red"). }\end{array}$ & $\begin{array}{l}\text { No } \\
\text { Rec. }\end{array}$ & $"$ \\
\hline $8 x$ & 8 & "، & " & " & $4^{\circ \mathrm{s}}$ & $\begin{array}{l}\text { Black with yellow } \\
\text { center. Subject } \\
\text { tried to banish } \\
\text { suggestion. }\end{array}$ & " & “ \\
\hline MIar. 22, '99 & $\begin{array}{r}9 \\
10\end{array}$ & “" & Cross. & ". & $\begin{array}{l}35 s \\
30 \mathrm{~s}\end{array}$ & $\begin{array}{l}\text { Dark green. } \\
\text { Green. }\end{array}$ & Oval. & “" \\
\hline Sept. 28, '99 & II & "6 & Disc. & Black. & $\begin{array}{l}30 \mathrm{~s} \\
20 \mathrm{~s}\end{array}$ & $\begin{array}{l}\text { Red square with } \\
\text { light green around } \\
\text { edge. }\end{array}$ & Sq. & “" \\
\hline Oct. 23, '99 & 12 & “ & “. & White. & 258 & $\begin{array}{l}\text { Green, no particu- } \\
\text { lar form. }\end{array}$ & & “" \\
\hline " & I3 & “" & “" & “" & 258 & $\begin{array}{l}\text { Green then violet } \\
\text { (violet had been } \\
\text { ruggested). }\end{array}$ & Disc. & " \\
\hline "“ & 14 & " & " & $\begin{array}{l}\text { Green } \\
\text { square. }\end{array}$ & $\begin{array}{l}\text { No } \\
\text { Rec. }\end{array}$ & $\begin{array}{l}\text { Colors reversed. } \\
\text { Green disc on red } \\
\text { square. }\end{array}$ & " & " \\
\hline Oct. 24, '99 & 15 & “ & “ & $\begin{array}{c}\text { Blue } \\
\text { square. }\end{array}$ & 256 & $\begin{array}{l}\text { Large yellow square } \\
\text { with small green } \\
\text { square inside and } \\
\text { blue on the out- } \\
\text { side of it. }\end{array}$ & Sq. & " \\
\hline " & 16 & " & "“ & $\begin{array}{l}\text { Black } \\
\text { square. }\end{array}$ & 158 & $\begin{array}{l}\text { Large black square } \\
\text { with small spot of } \\
\text { green inside. }\end{array}$ & Dot. & " \\
\hline
\end{tabular}

No. I 3 violet had been suggested as the after-color. The number of images with green in them is large. The writer has thought that perhaps the green image was somewhat after the 
nature of a positive after-image, the retinal light modifying the yellow to this extent, as mixing black with yellow would do, but is aware that the suggestion has, under the circumstances, little cogency.)

\section{Experiment with Presented Yeliow.}

On the closing of the eyes, after they had been stimulated for 30 seconds by spectral yellow, the after-image was described as blue and matched by 6 violet tint plus I $_{4}$ spectral blue.

Summary of Results for Violet. (Tamle IV.)

Total number of experiments, $I_{3}$.

Number of experiments without result, I.

After-colors: Deep yellow or orange, II ; violet, 2 ; green, 3 ; blue, $\mathrm{I}$.

(Note.-The green came each time as a border to the violet or orange. The blue was suggested as an after-effect and came after a blank interval.)

\section{Experiment with Presented Violet.}

On closing the eyes after they had been stimulated for 30 seconds by spectral violet upon a white background, the afterimage was described as orange and matched by 5 orange plus I 5 yellow.

Summary of Results for Red. (Table V.)

Total number of experiments, 16 .

Number of experiments without result, 0 .

After-colors: Green, Io; red, I ; black, 5 ; yellow, 4 ; violet, I.

(Note.-In No. 7 and No. 8 the subject was conscious of expecting black, and this probably accounts for the black. In No. I 3 violet had been suggested, and it appears after the green had been suppressed with effort.)

\section{Experiment with Presented Red.}

On the closing of the eyes after they had been stimulated for 30 seconds by spectral red upon a white background, the after-image was described as green and matched by green tint. 
Summary of Results for Green. (Table VI.)

Total number of experiments, $I_{4}$.

Number of experiments without result, 2.

After-colors : Violet-pink, red, and red-brown, ro; green, 3 ; violet, I; yellow, 2 ; black, I.

TABLE VI.

\begin{tabular}{|c|c|c|c|c|c|c|c|c|}
\hline \multicolumn{6}{|c|}{ Mental Image } & \multicolumn{3}{|c|}{ AFTER-IMAGE. } \\
\hline Dste. & No. & color. & Form. & $\begin{array}{l}\text { Back- } \\
\text { ground } \\
\text { upou } \\
\text { which } \\
\text { thrown }\end{array}$ & $\begin{array}{l}\text { Time } \\
\text { of } \\
\text { hold- } \\
\text { ing. }\end{array}$ & Color. & Form & $\begin{array}{c}\text { Back- } \\
\text { ground } \\
\text { upon } \\
\text { which } \\
\text { thrown }\end{array}$ \\
\hline Dec. 1,99 & $\begin{array}{l}1 \\
2\end{array}$ & $\underset{6}{\text { Green. }}$ & Cross & $\begin{array}{l}\text { White } \\
\text { In air }\end{array}$ & $\begin{array}{l}20 s \\
205\end{array}$ & Yellow. & Cross & White. \\
\hline Feb. $7, \infty$ & 3 & " & " & Black & $30 \mathrm{~s}$ & No results. & 6 & $\begin{array}{c}\text { Retinal } \\
\text { light. }\end{array}$ \\
\hline “ & 4 & $\begin{array}{l}\text { Dark } \\
\text { Green. }\end{array}$ & “ & $\because$ & fos & $\begin{array}{l}\text { Red-brown ( } 8 \mathrm{z} / 2 \\
\text { spectral red }+ \\
\left.\text { I I }^{2} / 2 \text { dark red }\right)\end{array}$ & ." & \\
\hline Mar. $7,{ }^{\prime} \infty$ & 5 & $\mid \begin{array}{l}\text { Spectral } \\
\text { green. }\end{array}$ & " & White & $30 s$ & $\begin{array}{l}\text { Gentian violet (ro } \\
\text { pink disc }+10 \\
\text { violet) changed to } \\
\text { brown. }\end{array}$ & “" & “ \\
\hline ". & 6 & “ & “ & $\begin{array}{l}\text { Retinal } \\
\text { light }\end{array}$ & $\begin{array}{l}\text { No } \\
\text { Rec'd }\end{array}$ & Spectral violet. & “ & White \\
\hline Mar. $14, \infty$ & 7 & Green. & “" & White & 305 & $\begin{array}{l}\text { Brown }(61 / 2 \text { spec- } \\
\text { tral yellow }+13 \% \\
\text { red). }\end{array}$ & “ & $\begin{array}{l}\text { Retinal } \\
\text { light. }\end{array}$ \\
\hline Me & 8 & “ & " & “ & $40 s$ & $\begin{array}{l}\text { Green in center, } \\
\text { brown outside. }\end{array}$ & “ & ." \\
\hline Mar. 22, ' $\infty$ & 9 & & Circle & “" & 405 & $\begin{array}{l}\text { Green with red in } \\
\text { center. }\end{array}$ & Circle & " \\
\hline$a_{0}$ & 10 & " & Sq. & “ & $30 s$ & $\begin{array}{l}\text { Green, then red } \\
\text { circle. }\end{array}$ & Sq. & $"$ \\
\hline Sept. $2 S$, ' $\infty$ & 11 & " & Disc. & White & $20 \mathrm{~s}$ & $\begin{array}{l}\text { Red blur over all } \\
\text { changed back to } \\
\text { green. }\end{array}$ & None & "“ \\
\hline Oct. $24, ' \infty$ & 12 & " & “ & Black & 20 s & $\begin{array}{l}\text { Red, then yellow. } \\
\text { Yellow had been } \\
\text { suggested. }\end{array}$ & Disc & . \\
\hline 16 & I3 & “ & & “ & $20 s$ & $\begin{array}{l}\text { Blank interval, then } \\
\text { black. Black had } \\
\text { been suggested. }\end{array}$ & & " \\
\hline “ & 14 & " & ، & $\begin{array}{l}\text { Red } \\
\text { square }\end{array}$ & 305 & $\begin{array}{l}\text { Big green square } \\
\text { with small red disc. }\end{array}$ & “ & ‘. \\
\hline
\end{tabular}

(Note.-In No. I 2 the yellow had been suggested and it appeared after the red had been suppressed. In No. I3 the black had been suggested and it appeared after a blank interval.) 
Experiment with Presented Green.

On the closing of the eyes after they had been stimulated for 30 seconds by spectral green upon a white background the after-image was described as reddish-pink and matched by 2 violet-tint plus 4 red plus $x_{4}$ rose-pink. The green visualized in the latter experiments was matched from memory by $9 x / 2$ black plus 1o $1 / 2$ spectral green, and the after-image from this was described as red and matched by 5 rose-pink plus i 5 spectral red. 